\title{
Penerapan Wanamina: Kelulushidupan Semai Mangrove, Variasi Kualitas Lingkungan dan Perubahan Kandungan Logam Berat
}

\section{Application of Silvofishery: Mangrove Seedling Survival, Variation of Environment Quality and Changes of Heavy Metal Concentration}

\author{
Endah Dwi Hastuti \\ Departemen Biologi, Fakultas Sains dan Matematika, Universitas Diponegoro \\ Jl. Prof. Soedarto, SH, Tembalang, Semarang \\ Email: endah_pdil@yahoo.com
}

Diterima 20 Desember 2016/Disetujui 17 Februari 2017

\begin{abstract}
ABSTRAK
Penerapan wanamina dalam budidaya tambak diharapkan memberikan perbaikan bagi lingkungan oleh adanya jasa-jasa lingkungan yang disediakan oleh tegakan mangrove. Penelitian ini bertujuan untuk mengkaji tingkat kelulushidupan semai mangrove, dampak wanamina terhadap tingkat kekeruhan dan kandungan TDS serta menganalisis perubahan kandungan logam berat dalam sedimen saluran tambak wanamina. Penelitian dilakukan selama 2 bulan pada tambak wanamina dengan perlakuan lebar saluran $1 \mathrm{~m}, 2 \mathrm{~m}$ dan $3 \mathrm{~m}$ dengan jenis mangrove A. marina dan $R$. mucronata dengan jarak tanam $1 \times 1 \mathrm{~m}^{2}$. Pengamatan terhadap tingkat kelulushidupan, tingkat kekeruhan dan kandungan TDS dilakukan pada akhir pengamatan, sedangkan kandungan $\mathrm{Pb}$ dan $\mathrm{Cd}$ dalam sedimen diamati pada awal dan akhir penelitian. Hasil penelitian menunjukkan bahwa tingkat kelulushidupan $R$. mucronata dalam saluran tambak wanamina lebih baik yaitu berkisar antara $80-90 \%$ dibandingkan A. marina yang berkisar $0-85 \%$. Kekeruhan secara signifikan berbeda berdasarkan lebar saluran sedangkan TDS secara signifikan dipengaruhi oleh lebar saluran dan jenis mangrove secara parsial. Perubahan kandungan $\mathrm{Pb}$ tidak dipengaruhi secara signifikan baik oleh lebar saluran maupun jenis mangrove, namun terdapat pola akumulasi yang berlawanan antara kedua jenis mangrove, sedangkan perubahan kandungan Cd secara signifikan dipengaruhi oleh lebar saluran dimana pada saluran dengan lebar 2 $\mathrm{m}$ memiliki tingkat akumulasi paling tinggi.
\end{abstract}

Kata kunci : kekeruhan, kelulushidupan, logam berat, TDS, wanamina

\begin{abstract}
The applicatin of silvofishery is expected to provide improvement on the environment through the environment services provided by mangrove stands. This research aimed to study the survival rate of mangrove seedling, the impact of applied silviculture on water turbidity and TDS concentration and to analyze the change of heavy metal concentration in the sediment of silvofishery pond canals. This research was conducted for 2 months in silvicultural pond including the treatment of canal width of $1 \mathrm{~m}, 2 \mathrm{~m}$ and $3 \mathrm{~m}$ and mangrove species of $A$. marina and $R$. mucronata planted in $1 \times 1 \mathrm{~m}^{2}$ plantation space. Observation on the survival rate of mangrove, turbidity and TDS concentraton was conducted at the end of research period, while observation on $\mathrm{Pb}$ and $\mathrm{Cd}$ in the sediment was conducted at the beginning and the end of the research. The result showed that the survival rate of $R$. mucronata in the silvicultural pond canal was better ranged from 80 $-90 \%$ compared to A. marina which was ranged from $0-85 \%$. Water turbidity variation was significantly affected by canal width while TDS was significantly affected by canal width and mangrove species partially. The changes of $\mathrm{Pb}$ concentration was not significantly affected by both treatments but there were inversed pattern of accumulation between species, while the changes of $\mathrm{Cd}$ concentration was significantly affected by canal width wich canal with $2 \mathrm{~m}$ width had highest accumulation rate.
\end{abstract}

Keywords : turbidity, survival rate, heavy metal, TDS, silvofish 


\section{PENDAHULUAN}

Penerapan wanamina dalam kegiatan budidaya tambak secara terpadu dengan upaya konservasi wilayah pesisir telah berkembang di berbagai wilayah di Indonesia (Setiawan et al., 2015). Jasa-jasa lingkungan yang disediakan ekosistem mangrove diharapkan mampu memberika kontribusi terhadap peningkatan produktivitas budidaya tambak (Udoh, 2016; Walters et al., 2008). Diantara jasa-jasa lingkungan yang disediakan, peran mangrove dalam pengendalian bahan pencemar merupakan salah satu fokus utama dalam penerapan sistem wanamina (Zhang et al., 2010). Perbaikan kualitas lingkungan dalam tambak menjadi indikator bagi peningkatan daya dukung lingkungan bagi kegiatan budidaya.

Vegetasi mangrove merupakan komponen penting dalam tambak wanamina. Mangrove sebagai penyedia jasa lingkungan dominan dalam tambak wanamina sangat penting berada dalam kondisi yang optimal (Sambu et al., 2013). Namun, pemaduan mangrove dalam tambak bukanlah hal yang mudah. Tingkat kematian yang tinggi merupakan kendala dalam utama dalam penerapan wanamina (Hastuti dan Budihastuti, 2016). Tegakan mangrove pada umumnya tumbuh pada kawasan pasang surut, sedangkan pada tambak pada umumnya tegakan mangrove akan selalu tergenang. Hal ini berdampak pada meningkatnya kerentanan tegakan semai sehingga mengganggu proses pemantapannya (Krauss et al., 2014).

Diantara berbagai jasa lingkungan yang disediakan oleh ekosistem mangrove adalah perbaikan kualitas lingkungan, baik secara fisika, kimia maupun biologis. Kualitas fisika lingkungan tambak merupakan salah satu faktor yang penting untuk ditingkatkan (Sachoemar et al., 2014). Tambak pada umumnya berada pada wilayah pesisir dengan dinamika kualitas air yang sangat fluktuatif. Adanya pengaruh pasang surut dan suplai air tawar dari aliran sungai berdampak pada perubahan kualitas lingkungan yang dapat berlangsung dengan cepat (Caffrey et al., 2007). Sedimen merupakan salah satu komponen yang seringkali terangkut oleh adanya dinamika tersebut.

Kandungan sedimen dalam air secara fisik dapat dilihat dari tingkat kekeruhannya, meskipun keberadaan komponen biologis seperti plankton juga memberikan kontribusi dalam menentukan tingkat kekeruhan air (Tanaka dan Kodama, 2007). Kekeruhan air memiliki pengaruh terhadap tingkat kesuburan perairan. Perairan yang keruh berdampak pada tingkat penetrasi sinar matahari yang rendah, sehingga proses fotosintesis akan terhambat yang berdampak pada rendahnya kemampuan perairan dalam mengurai bahan-bahan pencemar dan rendahnya kelimpahan plankton sebagai pakan alami bagi kultivan (Teng et al., 2007; Varadharajan dan Soundarapandian, 2014).

Selain tingkat kekeruhan, kandungan TDS (Total Dissolved Solids) merupakan faktor penting bagi kualitas air. Sedimen pada umumnya mengikat bahan-bahan pencemar sehingga semakin tinggi konsentrasi sedimen dalam air cenderung memiliki kandungan bahan pencemar yang tinggi pula, baik berupa bahan organik maupun logam. Secara struktural, mangrove berfungsi dalam peredaman laju aliran air sehingga meningkatkan laju sedimentasi sehingga konsentrasi TDS dapat diturunkan.

Selain kualitas fisik lingkungan, tegakan mangrove juga memiliki peranan penting dalam pengendalian kandungan logam berat (Lawson, 2011). Fungsi-fungsi pengendalian kandungan logam dalam perairan oleh mangrove meliputi proses peredaman aliran, akumulasi logam dalam sedimen, penyerapan oleh tegakan hingga akumulasi dalam organ (Kaewtubtim et al., 2016). Penurunan konsentrasi logam yang dialirkan ke dalam tambak merupakan salah satu indikator fungsi tegakan semai dalam penerapan tambak wanamina.

Dampak-dampak yang ditimbulkan dari penerapan wanamina dalam budidaya tambak belum banyak dipahami, khususnya terkait dengan fungsi tegakan mangrove dalam peningkatan kualitas lingkungan. Penelitian ini bertujuan untuk mengkaji tingkat kelulushidupan semai mangrove, mengkaji dampak wanamina terhadap tingkat kekeruhan dan kandungan TDS, dan menganalisis 
perubahan kandungan logam berat dalam sedimen saluran tambak wanamina.

\section{METODE PENELITIAN}

Penelitian dilakukan pada tambak wanamina dengan tegakan mangrove berupa Avicennia marina dan Rhizophora mucronata. Terdapat 3 formasi lebar saluran yang diterapkan dalam uji coba yang dilakukan, yaitu $1 \mathrm{~m} ; 2 \mathrm{~m}$; dan $3 \mathrm{~m}$ dimana pada masing-masing lebar tersebut terdapat sejumlah 5 tegakan, 10 tegakan dan 15 tegakan semai. Parameter-parameter yang diamati dalam penelitian ini meliputi tingkat kelulushidupan tegakan semak, perbedaan kandungan kekeruhan dan TDS pada saluran tambak, dan perubahan kandungan logam berat berupa $\mathrm{Pb}$ dan $\mathrm{Cd}$.

Penelitian dilaksanakan dari bulan Juli September 2016. Pengamatan tingkat kekeruhan dan kandungan TDS dilakukan pada akhir pengamatan, sedangkan pengujian kandungan logam berat pada sedimen dilakukan sebanyak 2 kali dengan jeda pengamatan selama 2 bulan. Analisis data dilakukan dengan ANOVA faktorial terhadap kekeruhan, kandungan TDS dan kandungan logam berat sedimen.

\section{HASIL DAN PEMBAHASAN}

Hasil pengamatan terhadap tingkat kelulushidupan semai dalam saluran tambak wanamina menunjukkan adanya perbedaan antara A. marina dan $R$. mucronata. Tingkat kelulushidupan $R$. mucronata berkisar antara $80 \%$ - $90 \%$ tercatat lebih tinggi dibandingkan dengan $A$. marina yang hanya berkisar antara $0 \%-85 \%$. Tingkat kelulushidupan semai mangrove tersebut bervariasi antar lebar saluran. Tabel 1 menunjukkan rincian tingkat kelulushidupan semai mangrove pada saluran tambak wanamina selama pengamatan.
Tabel 1. Tingkat kelulushidupan semai mangrove dalam saluran tambak wanamina

\begin{tabular}{ccc}
\hline Lebar & \multicolumn{2}{c}{ Jenis Mangrove } \\
\cline { 2 - 3 } Saluran & A. marina & R. mucronata \\
\hline $1 \mathrm{~m}$ & $0,00 \%$ & $80,00 \%$ \\
$2 \mathrm{~m}$ & $85,00 \%$ & $85,00 \%$ \\
$3 \mathrm{~m}$ & $60,00 \%$ & $90,00 \%$ \\
\hline
\end{tabular}

Tingkat kelulushidupan $R$. mucronata yang lebih tinggi dibandingkan dengan $A$. marina menunjukkan bahwa spesies tersebut memiliki daya tahan yang lebih baik terhadap gangguan lingkungan. Anwar (2007) menunjukkan bahwa $R$. mucronata lebih tahan terhadap genangan air dibandingkan dengan A. marina. Tingkat kelulushidupan A. marina pada tingkat genangan $0,8 \mathrm{~m}$ hanya sebesar $27,08 \%$ sedangkan pada $R$. mucronata mencapai $61,67 \%$. Selain disebabkan oleh daya toleransinya terhadap genangan, daya toleransi mangrove terhadap salinitas juga bervariasi. Beberapa jenis mangrove mampu mengakumulasi garam berlebih dalam sel daun sehingga dapat bertahan dalam lingkungan dengan tingkat salinitas yang tinggi (Kanai et al., 2014). Sementara Akello et al. (2014) menyatakan bahwa tingkat sedimentasi juga memiliki peranan penting bagi pertumbuhan mangrove.

Hasil pengamatan terhadap tingkat kekeruhan air menunjukkan bahwa terdapat variasi tingkat kekeruhan antar jenis mangrove dan lebar saluran. Tingkat kekeruhan paling tinggi teramati pada perlakuan saluran $1 \mathrm{~m}$ dengan mangrove $R$. mucronata. Sementara pada saluran $3 \mathrm{~m}$ dengan mangrove A. marina memiliki kekeruhan terendah. Hasil pengamatan menunjukkan bahwa terdapat penurunan kekeruhan seiring dengan pertambahan lebar saluran tambak pada tegakan $R$. mucronata.Tabel 2 menunjukkan rincian hasil pengukuran tingkat kekeruhan air dalam saluran tambak wanamina. 
Tabel 2. Variasi kekeruhan air dalam saluran tambak wanamina

\begin{tabular}{cccc}
\hline \multirow{2}{*}{ Lebar Saluran } & \multicolumn{2}{c}{ Jenis Mangrove } & \multirow{2}{*}{ (Rerata) } \\
\cline { 2 - 3 } & A. marina & $\boldsymbol{R}$. mucronata & \\
\hline \multirow{2}{*}{$1 \mathrm{~m}$} & $9,340-18,960$ & $16,530-23,880$ & $9,340-23,880$ \\
& $13,017 \pm 5,195^{\mathrm{x}}$ & $19,773 \pm 3,750^{\mathrm{x}}$ & $16,395 \pm 5,488^{\mathrm{p}}$ \\
\multirow{2}{*}{$\mathrm{m}$} & $9,980-22,350$ & $7,850-16,840$ & $7,850-22,350$ \\
& $17,893 \pm 6,871^{\mathrm{x}}$ & $11,580 \pm 4,686^{\mathrm{x}}$ & $14,737 \pm 6,295^{\mathrm{p}}$ \\
\multirow{2}{*}{$3 \mathrm{~m}$} & $4,080-8,840$ & $8,060-9,610$ & $4,080-9,610$ \\
& $7,200 \pm 2,703^{\mathrm{x}}$ & $8,693 \pm 0,813^{\mathrm{x}}$ & $7,947 \pm 1,964^{\mathrm{q}}$ \\
\hline \multirow{2}{*}{ (Rerata) } & $2,080-22,350$ & $7,850-23,880$ & \\
\hline
\end{tabular}

Keterangan : kelompok perlakuan yang ditandai dengan huruf yang sama menunjukkan tidak ada perbedaan yang signifikan pada taraf kepercayaan $95 \%$

Hasil pengujian statistik terhadap variasi kekeruhan air dalam saluran tambak wanamina menunjukkan bahwa terdapat perbedaan yang signifikan secara parsial berdasarkan lebar saluran tambak. Perbedaan signifikan teramati antara perlakuan dengan lebar saluran $1 \mathrm{~m}$ dan $2 \mathrm{~m}$ dengan lebar saluran $3 \mathrm{~m}$. Hasil pengujian diperoleh nilai $\mathrm{F}$ hitung sebesar 6,908 dengan probabilitas sebesar $0,010(\mathrm{p}<0,05)$. Sementara pengaruh secara parsial berdasarkan jenis mangrove maupun secara simultan tidak menunjukkan adanya pengaruh yang signifikan.

Penurunan turbiditas air seiring dengan semakin bertambahnya ukuran saluran meningkatkan laju pengangkutan sedimen. Hal ini didukung oleh Yu et al. (2014) yang mengamati tingkat kekeruhan pada aliran sungai menunjukkan bahwa penyempitan badan sungai mengakibatkan peningkatan kekeruhan air. Perubahan laju aliran merupakan faktor yang menentukan tingkat kekeruhan air dalam badan air. Goransson et al. (2013) menunjukkan bahwa semakin tinggi laju aliran mengakibatkan turbiditas yang rendah. Dalam saluran tambak wanamina, semakin lebar saluran tambak berdampak pada semakin besar aliran biomassa air sehingga kandungan sedimen menurun dan tingkat kekeruhan menjadi rendah.
Hasil pengujian kandungna TDS dalam saluran tambak wanamina menunjukkan adanya variasi antar perlakuan. Secara umum, kandungan TDS pada saluran dengan tegakan $R$. mucronata relatif lebih tinggi dibandingkan dengan pada tegakan A. marina. Pada saluran dengan tegakan $R$. mucronata, nampak adanya peningkatan kandungan TDS seiring dengan bertambahnya lebar saluran. Tabel 3 menunjukkan secara rini hasil pengamatan kandungan TDS dalam saluran tambak wanamina.

Pengujian statistik terhadap kandungan TDS air dalam saluran tambak wanamina menunjukkan adanya pengaruh yang signifikan secara parsial baik berdasarkan jenis mangrove maupun berdasarkan lebar saluran, namun pengaruh secara simultan dari kedua faktor pengamatan tidak terbukti secara nyata. Berdasarkan hasil pengujian statistik diperoleh nilai $F$ hitung sebesar 8,034 dengan probabilitas sebesar $0,006(\mathrm{p}<0,05)$ pada perlakuan lebar saluran dimana kandungan TDS pada saluran $1 \mathrm{~m}$ secara signifikan berbeda dengan saluran $2 \mathrm{~m}$ dan saluran $3 \mathrm{~m}$. Berdasarkan jenis mangrove, kandungan TDS pada tegakan $R$. mucronata secara signifikan lebih tinggi dibandingkan dengan pada tegakan A. marina dengan $\mathrm{F}$ hitung sebesar 8,878 dengan probabilitas sebesar 0,011(p<0,05). 
Tabel 3. Variasi kandungan TDS dalam saluran tambak wanamina

\begin{tabular}{|c|c|c|c|}
\hline \multirow{2}{*}{ Lebar Saluran } & \multicolumn{2}{|c|}{ Jenis Mangrove } & \multirow{2}{*}{ (Rerata) } \\
\hline & A. marina & R. mucronata & \\
\hline \multirow[t]{2}{*}{$1 \mathrm{~m}$} & $230,300-288,190$ & $302,350-340,290$ & $230,300-340,290$ \\
\hline & $263,103 \pm 29,706^{\mathrm{x}}$ & $322,753 \pm 19,132^{\mathrm{x}}$ & $292,928 \pm 39,583^{\mathrm{p}}$ \\
\hline \multirow[t]{2}{*}{$2 \mathrm{~m}$} & $315,670-382,190$ & $340,920-367,460$ & $315,670-382,190$ \\
\hline & $349,753 \pm 33,291^{x}$ & $354,560 \pm 13,285^{x}$ & $352,157 \pm 22,822^{q}$ \\
\hline \multirow[t]{2}{*}{$3 \mathrm{~m}$} & $280,310-329,900$ & $330,250-390,120$ & $280,310-390,120$ \\
\hline & $313,260 \pm 28,536^{\mathrm{x}}$ & $360,890 \pm 29,960^{\mathrm{x}}$ & $337,075 \pm 396,951^{q}$ \\
\hline \multirow[t]{2}{*}{ (Rerata) } & $230,300-382,190$ & $302,350-390,120$ & \\
\hline & $308,706 \pm 46,051^{\mathrm{a}}$ & $345,068 \pm 25,948^{\mathrm{b}}$ & \\
\hline
\end{tabular}

Keterangan : kelompok perlakuan yang ditandai dengan huruf yang sama menunjukkan tidak ada perbedaan yang signifikan pada taraf kepercayaan $95 \%$

Kandungan TDS yang lebih tinggi pada saluran dengan tegakan $R$. mucronata disebabkan oleh sistem perakaran mangrove yang lebih kompleks dibandingkan pada tegakan A. marina (Tamooh et al., 2008). Perakaran yang kompleks tersebut berakibat pada penurunan kecepatan arus sehingga terjadi akumulasi kandungan TDS dalam air (Alshawafi et al., 2016). Akar nafas pada $R$. mucronata terbentuk dari batang sehingga memiliki ukuran yang lebih besar dan efektif dalam meredam aliran air dan memerangkap sedimen.

Kandungan TDS pada saluran $1 \mathrm{~m}$ lebih rendah karena kelimpahan mangrove yang rendah. Dengan jarak tanam yang sama, saluran dengan lebar yang lebih besar menghasilkan jumlah tegakan yang lebih banyak sehingga perakaran yang dihasilkan juga lebih kompleks (Kathiresan, 2003). Hal ini membantu fungsi pemerangkapan sedimen dalam saluran mangrove. Alshawafi et al. (2016) menjelaskan bahwa jumlah akar per satuan luas mepengaruhi kandungan TDS dalam air di sekitar tegakan mangrove.

Analisis laboratorium terhadap kandungan $\mathrm{Pb}$ dalam saluran tambak wanamina menunjukkan adanya variasi antar perlakuan. Berdasarkan hasil pengolahan data, secara umum kandungan $\mathrm{Pb}$ pada saluran dengan tegakan $R$. mucronata relatif lebih tinggi dibandingkan dengan A. marina. Terdapat kecenderungan peningkatan tingkat akumulasi kandungan $\mathrm{Pb}$ sedimen seiring dengan bertambahnya lebar saluran pada saluran dengan tegakan $R$. mucronata, namun sebaliknya pada saluran dengan tegakan $A$. marina tingkat akumulasi $\mathrm{Pb}$ justru cenderung menurun. Rincian perubahan kandungan $\mathrm{Pb}$ dalam sedimen pada saluran tambak wanamina disajikan pada Tabel 4.

Tabel 4 menunjukkan bahwa pola perubahan kandungan $\mathrm{Pb}$ dalam saluran tambak wanamina relatif beragam. Pada beberapa perlakuan nampak terjadinya penurunan antar pengamatan, sedangkan sebagian yang lain justru mengalami peningkatan. Hasil analisis data menunjukkan bahw abaik secara parsial maupun simultan tidak ada perbedaan yang nyata terhadap perbedaan tingkat perubahan kandungan $\mathrm{Pb}$ dalam sedimen saluran tambak wanamina.

Akumulasi kandungan $\mathrm{Pb}$ dalam sedimen pada kedua jenis mangrove memiliki pola yang berbeda. Pada tegakan A. marina semakin besar lebar saluran justru semakin kecil tingkat akumulasinya. Sebaliknya, pada tegakan $R$. mucronata semakin besar lebar saluran semakin tinggi pula tingkat akumulasinya. Akumulasi logam pada sedimen mangrove ditentukan oleh beberapa faktor, antara lain laju sedimentasi dan laju penyerapan oleh tegakan. Beberapa penelitian menunjukkan bahwa tegakan mangrove secara aktif mengakumulasi logam berat dalam organ tanaman (Kathiresan et al., 2014; Pakzadtoochaei, 2013; Erakhrumen, 2015; Kamaruzzaman et al., 2009). Penelitian Kaewtubtim et al. (2016) secara 
rinci menunjukkan bahwa akumulasi $\mathrm{Pb}$ dalam organ tanaman A. marina lebih tinggi dibandingkan pada $R$. mucronata. Hal ini menjelaskan penyebab semakin menurunnya akumulasi kandungan $\mathrm{Pb}$ dalam sedimen dibawah tegakan A. marina dibandingkan tegakan $R$. mucronata selama penelitian.

Tabel 4. Variasi perubahan kandungan $\mathrm{Pb}$ dalam sedimen pada saluran tambak wanamina

\begin{tabular}{cccc}
\hline \multirow{2}{*}{ Lebar Saluran } & \multicolumn{2}{c}{ Jenis Mangrove } & \multirow{2}{*}{ (Rerata) } \\
\cline { 2 - 3 } & \multicolumn{1}{c}{$\boldsymbol{A}$ marina } & $\boldsymbol{R}$. mucronata & \\
\hline \multirow{2}{*}{$1 \mathrm{~m}$} & $0,345-1,990$ & $0,337-0,730$ & $0,337-1,990$ \\
& $1,045 \pm 0,849^{\mathrm{x}}$ & $0,564 \pm 0,203^{\mathrm{x}}$ & $0,805 \pm 0,612^{\mathrm{p}}$ \\
$\mathrm{2} \mathrm{m}$ & $-1,613-2,335$ & $-0,378-1,830$ & $-1,613-2,335$ \\
& $0,837 \pm 2,139^{\mathrm{x}}$ & $0,755 \pm 1,105^{\mathrm{x}}$ & $0,796 \pm 1,524^{\mathrm{p}}$ \\
\multirow{2}{*}{$3 \mathrm{~m}$} & $-1,165-0,762$ & $0,535-1,490$ & $-1,165-1,490$ \\
& $0,063 \pm 1,067^{\mathrm{x}}$ & $1,080 \pm 0,492^{\mathrm{x}}$ & $0,571 \pm 0,929^{\mathrm{p}}$ \\
\hline \multirow{2}{*}{ (Rerata) } & $-1,613-2,335$ & $-0,378-1,830$ & \\
\hline
\end{tabular}

Keterangan : kelompok perlakuan yang ditandai dengan huruf yang sama menunjukkan tidak ada perbedaan yang signifikan pada taraf kepercayaan $95 \%$

Uji laboratorium terhadap kandungan $\mathrm{Cd}$ menunuukkan adanya variasi antar pengamatan. Hasil pengolahan data menunjukkan bahwa terdapat kesamaan pola perubahan kandungan $\mathrm{Cd}$ dalam sedimen dari kedua jenis tegakan mangrove. Berdasarkan hasil pengamatan, diketahui bahwa pada perlakuan dengan lebar saluran $2 \mathrm{~m}$ akumulasi logam $\mathrm{Cd}$ lebih tinggi dibandingkan dengan lebar saluran $1 \mathrm{~m}$ dan $3 \mathrm{~m}$ yang tercatat rendah. Tabel 5 menunjukkan variasi perubahan kandungan $\mathrm{Cd}$ dalam sedimen saluran tambak wanamina secara rinci.

Tabel 5. Variasi perubahan kandungan Cd dalam sedimen pada saluran tambak wanamina

\begin{tabular}{|c|c|c|c|}
\hline \multirow{2}{*}{ Lebar Saluran } & \multicolumn{2}{|c|}{ Jenis Mangrove } & \multirow{2}{*}{ (Rerata) } \\
\hline & A. marina & R. mucronata & \\
\hline \multirow[t]{2}{*}{$1 \mathrm{~m}$} & $-0,305-0,435$ & $-0,300-0,118$ & $-0,305-0,435$ \\
\hline & $0,120 \pm 0,382^{\mathrm{x}}$ & $-0,094 \pm 0,209^{x}$ & $0,013 \pm 0,299^{p}$ \\
\hline \multirow[t]{2}{*}{$2 \mathrm{~m}$} & $0,402-0,845$ & $-0,063-0,620$ & $-0,063-0,845$ \\
\hline & $0,641 \pm 0,224^{\mathrm{x}}$ & $0,226 \pm 0,354^{\mathrm{x}}$ & $0,433 \pm 0,349^{q}$ \\
\hline \multirow[t]{2}{*}{$3 \mathrm{~m}$} & $-0,375-0,263$ & $-0,255-0,405$ & $-0,375-0,405$ \\
\hline & $-0,043 \pm 0,320^{x}$ & $-0,025 \pm 0,373^{x}$ & $-0,034 \pm 0,311^{\mathrm{p}}$ \\
\hline (Rerata) & $\begin{array}{l}-0,375-0,845 \\
0,269 \pm 0,413^{\mathrm{a}}\end{array}$ & $\begin{array}{l}-0,300-0,620 \\
0,036 \pm 0,313^{\mathrm{a}}\end{array}$ & \\
\hline
\end{tabular}

Keterangan : kelompok perlakuan yang ditandai dengan huruf yang sama menunjukkan tidak ada perbedaan yang signifikan pada taraf kepercayaan $95 \%$

Hasil analisis data menunjukkan bahwa perlakuan lebar saluran memberikan pengaruh yang signifikan terhadap perubahan kandungan $\mathrm{Cd}$ dalam sedimen saluran tambak wanamina, sementara perlakuan berdasarkan jenis mangrove dan secara simultan tidak menunjukkan adanya perbedaan yang signifikan. Berdasarkan hasil pengujian yang telah dilakukan, diperoleh nilai $\mathrm{F}$ 
hitung sebesar 3,935 dengan probabilitas sebesar $0,049(\mathrm{p}<0,05)$.

Adanya variasi perubahan kandungan $\mathrm{Cd}$ berdasarkan lebar saluran menunjukkan bahwa terdapat perbedaan keseimbangan antara laju sedimentasi dan laju penyerapan $\mathrm{Cd}$ oleh tegakan mangrove. Baik pada saluran dengan tegakan $A$. marina maupun $R$. mucronata, saluran dengan lebar $2 \mathrm{~m}$ memiliki tingkat akumulasi paling tinggi dibandingkan dengan lebar saluran lain. Akumulasi logam berat dalam sedimen menurut Olubunmi dan Olorunsola (2010) dipengaruhi oleh beberapa faktor, antara lain musim, volume buangan dari industri dan kawasan pemukiman, serta fenomena geologis yang menyebabkan terjadinya pengayaan logam berat. Varz et al. (2012) menunjukkan bahwa tegakan mangrove memiliki kemampuan mengakumulasi logam, namun terdapat keterbatasan dalam kemampuan akumulasinya pada setiap organ tanaman. Hasil penelitian ini mengindikasikan bahwa pada saluran dengan lebar $1 \mathrm{~m}$ tingkat sedimentasi relatif rendah sehingga akumulasi sedimen juga rendah, sedangkan pada lebar saluran $2 \mathrm{~m}$ tingkat penyerapan lebih tinggi, sehingga meskipun terdapat akumulasi logam yang tinggi namun sebagian besar diserap oleh tegakan mangrove.

\section{KESIMPULAN}

Jenis mangrove $R$. mucronata memiliki daya tahan yang lebih baik dari A. marina pada penanaman dalam saluran tambak wanamina yang dibuktikan dengan tingkat kelulushidupannya yang lebih tinggi. Tingkat kekeruhan air secara signifikan dipengaruhi oleh lebar saluran, dimana semakin sempit ukuran saluran berdampak pada semakin tingginya tingkat kekeruhan air. Kandungan TDS air dipengaruhi oleh lebar saluran dan jenis mangrove dimana bertambahnya ukuran lebar saluran meningkatkan kandungan TDS, disisi lain kandungan TDS air juga lebih tinggi dibawah tegakan $R$. mucronata. Kandungan $\mathrm{Pb}$ sedimen tidak dipengaruhi oleh lebar saluran maupun jenis mangrove, namun terdapat pola akumulasi yang bertolak belakang antara saluran dengan tegakan A. marina dan $R$. mucronata, sedangkan akumulasi kandungan $\mathrm{Cd}$ secara signifikan lebih tinggi pada saluran dengan lebar $2 \mathrm{~m}$.

\section{UCAPAN TERIMA KASIH}

Penelitian ini dibiayai dengan Sumber Dana PNBP DIPA Universitas Diponegoro Semarang tahun anggaran 2016.

\section{DAFTAR PUSTAKA}

Alshawafi, A., Analla A., Aksissou M. dan Triplet P. 2016. Physicochemical Properties of Water, Soil and Morphological Characteristics of Mangrove Forests in the Island of Kamaran, Al Hodaidah, Yemen. Journal of Ecosystem and Ecography 6(4): 1000211.

Anwar, C. 2007. Pertumbuhan Anakan Mangrove pada Berbagai Jarak Tanam dan Tingkat Penggenangan Air Laut di Pemalang, Jawa Tengah. Jurnal Penelitian Hutan dan Konservasi Alam 4(4): 353 - 364.

Caffrey, J.M., Chapin T.P., Jannasch H.W. dan Haskins J.C. 2007. High Nutrient Pulses, Tidal Mixing and Biological Response in A Small California Estuary: Variability in Nutrient Concentrations from Decadal to Hourly Time Scales. Estuarine, Coastal and Shelf Science 71: $368-380$.

Erakhrumen, A.A. 2015. Assessment of In-Situ Natural Dendroremediation Capability of Rhizophora racemosa in Heavy Metal Polluted Mangrove Forest, River State, Nigeria. J. Appl. Sci. Environ. Manage. 19(1): $21-27$.

Goransson, G., Larson M. dan Bendz D. 2013. Variation in Turbidity with Precipitation and Flow in A Regulated River System - River Gota Alv, SW Sweden. Hydrol. Earth Syst. Sci. 17: $2529-2542$.

Hastuti, E.D dan Budihastuti, R. 2016. Analysis on the Absolute Growth Rate of Rhizophora mucronata Seedling in Silvicultural Pond Canals by the Influence of Initial Condition and Changes of Environment Quality. Biosaintifika 8(1): $56-63$. 
Kaewtubtim, P., Meeinkuirt W., Seepom S. dan Pichtel J. 2016. Heavy Metal Phytoremediation Potential of Plant Species in A Mangrove Ecosystem in Pattani Bay, Thailand. Applied Ecology and Environmental Research 14(1): 367 - 382.

Kamaruzzaman, B.Y., Ong M.C., Jalal K.C.A., Shahbudin S. dan Nor O.M. 2009. Accumulation of Lead and Copper in Rhizophora apiculata from Setiu Mangrove Forest, Terengganu, Malaysia. Journal of Environmental Biology 30(5): 821 - 824.

Kanai, H., Tajima M. dan Sakai A. 2014. Effect of Salinity on the Growth and Survival of the Seedlings of Mangrove, Rhizophora stylosa. International Journal of Plant \& Soil Science 3(7): $879-893$.

Kathiresan, K. 2003. How Do Mangrove Forests Induce Sedimentation? Rev. Biol. Trop. 51(2): $355-360$.

Kathiresan, K., Saravanakumar K. dan Mullai P. 2014. Bioaccumulation of Trace Elements by Avicennia marina. Journal of Coastal Life Medicine 2(11); 888 - 894.

Kewtubtim, P., Meeinkuirt W., Seepom S. dan Pitchtel J. 2016. Heavy Metal Phytoremediation Potential of Plant Species in A Mangrove Ecosystem in Pattani Bay, Thailand. Applied Ecology and Environmental Research 14(1): 367 - 382 .

Krauss, K.W., McKee K.L., Lovelock C.E., Cahoon D.R., Saintilan N., Reef R. dan Chen L. 2014. How Mangrove Forests Adjust to Rising Sea Level. New Phytologist 202: 19 - 34 .

Lawson, E.O. 2011. Physico-Chemical Parameters and Heavy Metal Contents of Water from the Mangrove Swamps of Lagos Lagoon, Lagos, Nigeria. Advances in Biological Research 5(1): $8-21$.

Okello, J.A., Robert E.M.R., Beeckman H., Kairo J.G., Dahdouh-Guebas F. dan Koedam N. 2014. Effects of Expermental Sedimentation on the Phenological Dynamics and Leaf Traits of Replanted Mangroves at Gazy Bay, Kenya. Ecology and Evolution 4(16): 3187 $-3200$.
Olubunmi, F.E. dan Olorunsola O.E. 2010. Evaluation of the Status of Heavy Metal Pollution of Sediment of Agbabu Bitumen Deposit Area, Nigeria. European Journal of Scientific Research 41(3): 373 - 382.

Pakzadtoochaei, S. 2013. Comparing the Concentration of Heavy Metals $(\mathrm{Cd}, \mathrm{Cu}, \mathrm{Ni}$ and $\mathrm{Zn}$ ) in the Sediment and Different Tissues of Avicennia marina in Iranian Coasts of Oman Sea. International Research Journal of Applied and Basic Sciences 4(3): $561-569$.

Sachoemar, S.I., Yanagi T. dan Aliah R.S. 2014. Sustainable Aquaculture to Imrpove Productivity and Water Quality of Marginal Brackishwater Pond. Coastal Marine Science 37(1): $1-8$.

Sambu, A.H., Damar A., Bengen D.G. dan Yulianda F. 2013. Desain Tambak Silvofishery Ramah Lingkungan Berbasis Daya Dukung: Studi Kasus Kelurahan Samataring, Kabupaten Sinjai. J. Segara 9(2): $157-165$.

Setiawan, Y., Bengen D.G., Kusmana C. dan Pertiwi, S. 2015. Estimasi Nilai Eksternalitas Konversi Hutan Mangrove Menjadi Pertambakan di Delta Mahakam Kabupaten Kutai Kartanegara. Jurnal Penelitian Hutan Tanaman 12(3): 201 - 210.

Tamooh, F., Huxham M., Karachi M., Mencuccini M., Kairo J.G. dan Kirui B. 2008. BelowGround Root Yield and Distribution in Natural and Replanted Mangrove Forests at Gazy Bay, Kenya. Forest Ecology and Management 256: 1290 - 1297.

Tanaka, K. dan Kodama M. 2007. Effects of Resuspended Sediments on the Environmental Changes in the Inner Part of Ariake Bay, Japan. Bull. Fish. Res. Agen. 19: $9-15$.

Teng ,W., Guoxiang W. dan Qiang L. 2007. Effects of Water Turbidity on the Photosynthetic Characteristics of Myriophyllum spicatum L. Asian Journal of Plant Sciences 6(5): 773 - 780. 
Udoh, J.P. 2016. Sustainable Nondestructive Mangrove-Friendly Aquaculture in Nigeria II: Models, Best Practices and Policy Frame Work. AACL Bioflux 9(1): 151 - 173.

Varadharajan, D. dan Soundarapandian P. 2014. Effect of Physico-Chemical Parameters on Species Biodiversity with Special Reference to the Phytoplankton from Muthupettai, South East Coast of India. J. Earth Sci. Clim. Change 5(5): 1000200

Varz, M.K., Mohammadika D., Gharibpour F. dan Dabbagh A.-R. 2012. Accumulation of Heavy Metals $(\mathrm{Pb}, \mathrm{Cd}, \mathrm{V})$ in Sediment, Roots and Leaves of Mangrove Species in Sirik Creek Along the Sea Coasts of Oman, Iran. J. Appl. Sci. Environ. Manage. 16(4): $323-326$. 